\title{
Recent advances in bioprinting techniques: approaches, applications and future prospects
}

\author{
Jipeng $\mathrm{Li}^{\dagger}$, Mingjiao Chen ${ }^{\dagger}$, Xianqun Fan ${ }^{*}$ and Huifang Zhou ${ }^{*}$
}

\begin{abstract}
Bioprinting technology shows potential in tissue engineering for the fabrication of scaffolds, cells, tissues and organs reproducibly and with high accuracy. Bioprinting technologies are mainly divided into three categories, inkjet-based bioprinting, pressure-assisted bioprinting and laser-assisted bioprinting, based on their underlying printing principles. These various printing technologies have their advantages and limitations. Bioprinting utilizes biomaterials, cells or cell factors as a "bioink" to fabricate prospective tissue structures. Biomaterial parameters such as biocompatibility, cell viability and the cellular microenvironment strongly influence the printed product. Various printing technologies have been investigated, and great progress has been made in printing various types of tissue, including vasculature, heart, bone, cartilage, skin and liver. This review introduces basic principles and key aspects of some frequently used printing technologies. We focus on recent advances in three-dimensional printing applications, current challenges and future directions.
\end{abstract}

Keywords: Tissue engineering, 3D bioprinting, Artificial organs

\section{Background}

The loss or failure of organs and tissues is a difficult and costly problem in healthcare. The limited supply of organs globally [1] has motivated research on tissue engineering, particularly the design of a cell-scaffoldmicroenvironment to promote the regeneration of various types of tissue, e.g., skin [2], cartilage [3], bone [4], tendon [5] and cardiac tissue [6].

Scaffolds are considered the key element for tissue regeneration because they provide the necessary mechanical support and a physical structure for the transplanted cells to attach, grow and maintain their physiological functions. A suitable scaffold, such as a bone scaffold for tissue engineering, must have favorable biocompatibility or cytocompatibility to provide a surface for cells to adhere, proliferate, differentiate and secrete extracellular matrix (ECM). ECM contains abundant

\footnotetext{
*Correspondence: fanxq@sh163.net; fangzzfang@163.com ${ }^{\dagger}$ Jipeng Li and Mingjiao Chen contributed equally to this work Department of Ophthalmology, Ninth People's Hospital, Shanghai Jiao Tong University School of Medicine, Shanghai 200011, People's Republic of China
}

bioactive molecules, including glycosaminoglycans, collagen, fibronectin and cytokines. Pore size and interconnectivity also play important roles in cell adhesion and migration, vascularization and new tissue ingrowth [7-11]. Thus, a fully satisfactory scaffold must simultaneously support the growth of different cell types and tissues, each with specific mechanical properties, chemical gradients, cell populations, and geometric structures. However, conventional fabrication methods $[12,13]$ used for manufacturing three-dimensional (3D) scaffolds, such as electrospinning, fiber deposition, freeze-drying, gas foaming, and salt leaching, lack precise control of internal structural features and topology. Therefore, techniques for the accurate fabrication of multifunctional scaffolds are needed. These complex design constraints limit the effectiveness of many current traditional methods, particularly when attempting to repair clinically relevant injuries, organs, and other complex tissues.

Additive manufacturing (AM) technology is increasingly recognized as a potential solution for constructing complex interfacial tissue engineering scaffolds. AM forms complex 3D biocompatible structures via 
automated deposition of biological substances on a substrate using computer-aided design/computer-aided manufacturing (CAD/CAM) technology. The working principle of AM is that objects can be created by adding material in a layer-by-layer manner, in contrast to conventional machining, which removes material in a subtractive manner [14]. 3D bioprinting is an important type of the AM technology which focus on printing bioactivity substance. Bioprinting can control the shape, size, internal porosity and interconnectivity of a tissue-engineering scaffold (Fig. 1). Moreover, some types of bioprinting technology are capable of fixed-point deposition of cells and biomolecules, such as DNA, Polycose ${ }^{\circledR}$ and cytokines. Micro-tissues, micro-organs or mimetic extracellular matrix (mECM) can provide researchers with an effective strategy to study disease progression [15] and mechanisms of drug action $[16,17]$, in addition to applications in tissue or organ transplantation $[18,19]$.

3D bioprinting technology has attracted increasing attention based on its immense potential in the manufacture of tissue-engineering compounds. This review focuses on the key elements of 3D bioprinting technology used to fabricate very precise scaffolds and the applications of printing-specific modeling used in patient preoperative planning and the production of artificial tissues or organs for implantation. The article also discusses challenges and potential future directions.

\section{Bioprinting technologies and their applications}

We have summarized 3D printing techniques frequently utilized for scaffold fabrication, cell behavior studies and tissue repair (Table 1).

\section{Inkjet-based bioprinting}

Inkjet-based bioprinting is a type of bioprinting technology based on the conventional inkjet printing process with desktop inkjet printers. It is a noncontact printing process that deposits precise picoliter droplets of "bioink" onto a hydrogel substrate or culture dish under computer control. The common methods can be further classified into thermal and piezoelectric actuator methods based on the droplet actuation mechanism [20]. In thermal technology, ink droplets are generated by heating so that an inflated bubble forces the ink out of the narrow nozzle and onto the substrates (Fig. 2a). The localized temperature can reach hundreds of degrees in only a few microseconds to generate pulse pressure [21]. This technology is inexpensive and has been used broadly $[22,23]$. However, the droplets prepared using the thermal technology are mixed, unordered and unequal in size. Because of frequent nozzle blockages, smooth printing is difficult. Shear and thermal stress also affect the viability of the cellular and protein inks [24]. In piezoelectric technology, drops are generated by the transient pressure from piezoelectric actuator (Fig. 2b). In contrast to thermal

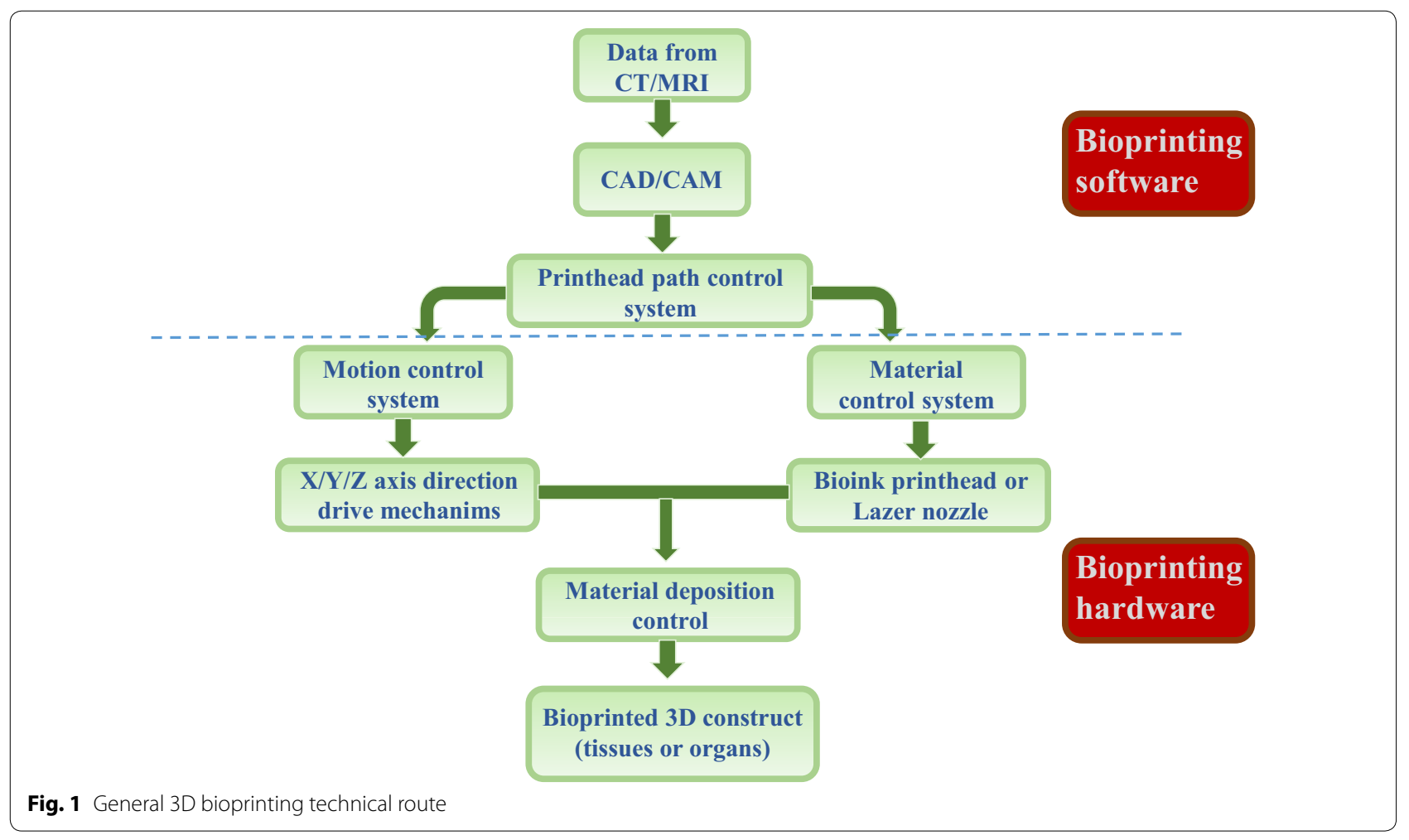




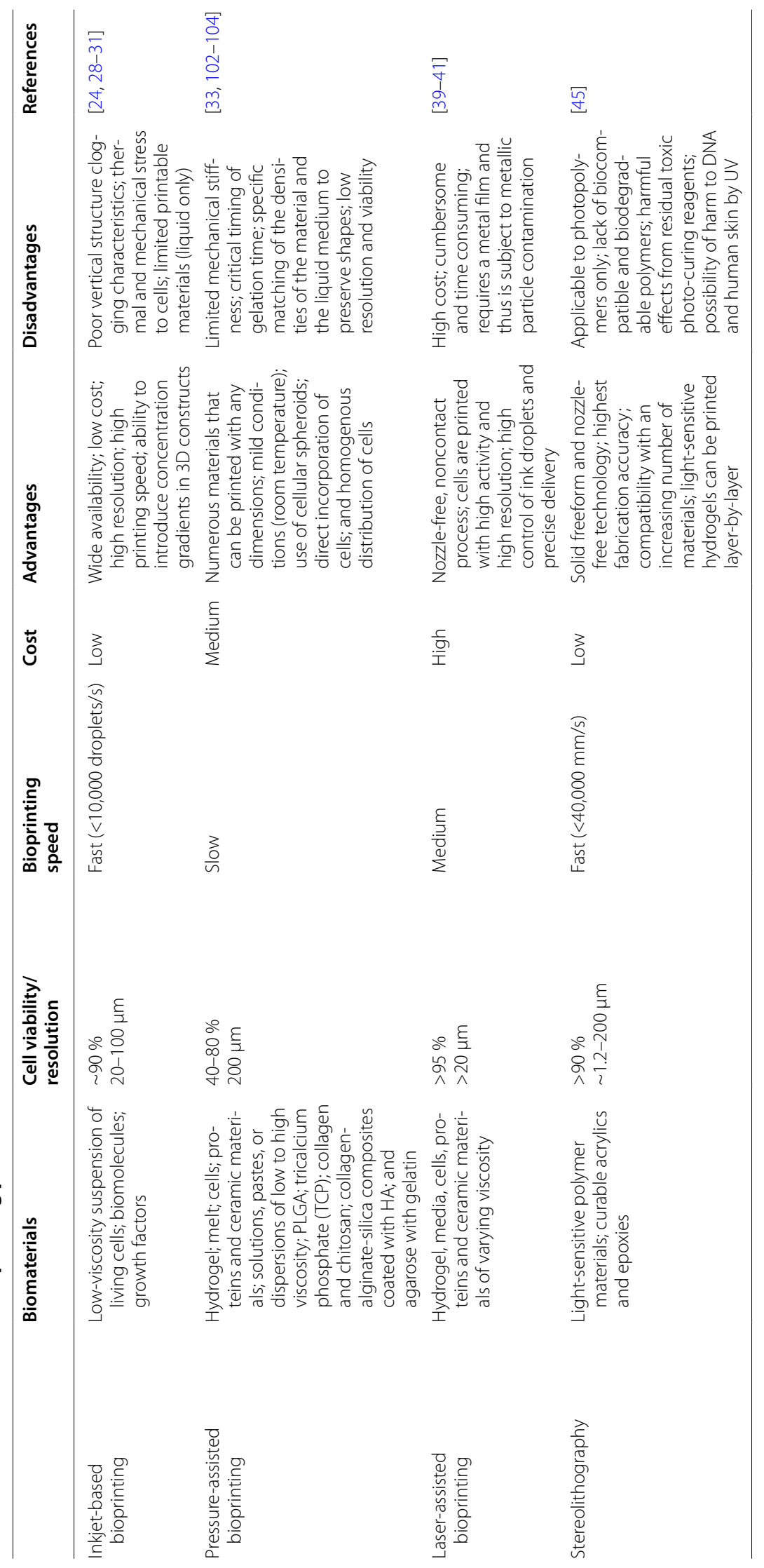



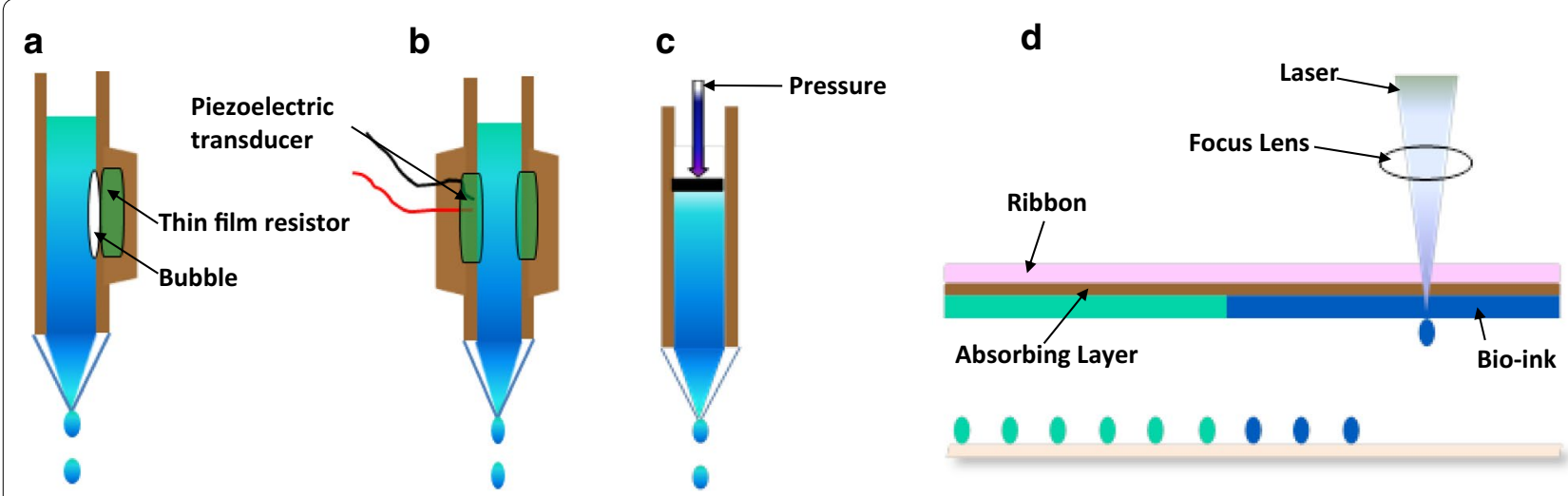

Fig. 2 Common types of bioprinting methods. a Thermal inkjet-based bioprinting technology utilizes an electric current pulse that impulses the thin film resistor, then generates bubbles that create a pressure pulse that propels the ink droplet onto the substrates. $\mathbf{b}$ A piezoelectric transducer creates a pulse that creates transient pressure, resulting in droplet ejection. c Pressure-assisted bioprinting uses solutions, pastes, or dispersions as biomaterials, which are extruded by pressure in the form of a continuous filament through a microscale nozzle orifice or a microneedle. $\mathbf{d}$ Laserassociated bioprinting consists of three parts: a pulsed laser source, a ribbon and a receiving substrate. The lasers irradiate the ribbon, causing the liquid biological materials to evaporate and reach the receiving substrate in droplet form

technology, the piezoelectric method does not use heat and does not cause orifice clogging, allowing droplets to remain directional with regular and equal size $[25,26]$. However, piezoelectric technology can cause damage to the cell membrane and cell lysis if used too frequently [27]. Greater than $90 \%$ viability has been reported for piezoelectrically deposited mammalian cells, including human osteoblasts, fibroblasts, and bovine chondrocytes [26].

Scientists have made great progress in patterning molecules, cells and organs by inkjet printing. Molecules such as DNA have been successfully printed [28], facilitating studies of cancer pathogenesis and treatment. In addition, thermal inkjet printing has been demonstrated to be biocompatible with Chinese hamster ovary $(\mathrm{CHO})$ cells and rat embryonic motoneurons [29]. Less than $8 \%$ of $\mathrm{CHO}$ cells were lysed in the printing process, indicating that mammalian cells can be successfully printed by inkjet bioprinting and retain their functions, with good prospects for creating living tissue structures or organs. Further developments in bioprinting technology have resulted in advancements in the printing of functional blood vessels and heart valves. In 2015, Jana and Lerman studied the bioprinting of cardiac valves to solve clinical transplantation shortages. Cardiac constructs are complex and important, particularly the four valves of the heart. Although heart valves have been successfully printed, the functional requirements of elasticity and physiological conditions remain to be fulfilled [24]. Similarly, in 2014, Duan B examined printing of blood vessels and observed drawbacks similar to those observed for bioprinted heart valves. Hydrogels, the main biomaterials used in inkjet bioprinting, are too soft to withstand normal physiological conditions [30, 31]. Thus, to successfully print organs that maintain good biological function in vivo, new biological materials that are more suitable for the human body must be developed to match the mechanical and biological properties of native organs.

\section{Pressure-assisted bioprinting and its applications}

Pressure-assisted bioprinting (PAB) is based on extrusion to create desired 3D patterns and constructs. The biomaterials used for printing are usually solutions, pastes, or dispersions [32] that are extruded by coordinating the motion of pneumatic pressure or plunger- or screwbased pressure in the form of a continuous filament through a microscale nozzle orifice or a microneedle onto a stationary substrate. After layer-by-layer application, complete 3D patterns and constructs are eventually formed (Fig. 2c).

The advantages of PAB technology include room temperature processing, direct incorporation of cells and homogenous distribution of cells. PAB has been applied to the printing of cell and organs with confirmed retention of activity. Bioprinted cells include mouse pre-osteoblasts, human mesenchymal stem cells, endothelial cells, and osteogenic progenitors. Bioprinted cells have been used to repair ovine calvarial defects [33]. The feasibility of multicellular bioprinted constructs incorporating goat multipotent stromal cells (MPSCs) and endothelial progenitor cells with retention of heterogeneous cell organization in the subcutaneous tissue of immunodeficient mice and production extracellular matrix has been demonstrated. The multipotent stromal cells in the multicellular bioprinted constructs differentiated into bone 
structures, and the endothelial progenitor cells differentiated into blood vessels. These results support the ability of multicellular bioprinted grafts to retain activity in vivo $[34,35]$.

\section{Laser-assisted bioprinting}

Laser-assisted bioprinting (LAB) uses a laser as the energy source to deposit biomaterials onto a substrate. This technique usually consists of three parts: a pulsed laser source, a ribbon coated with liquid biological materials that are deposited on the metal film, and a receiving substrate [24]. The lasers irradiate the ribbon, causing the liquid biological materials to evaporate and reach the receiving substrate in droplet form. The receiving substrate contains a biopolymer or cell culture medium to maintain cellular adhesion and sustained growth after transfer of cells from the ribbon (Fig. 2d). LAB mainly uses nanosecond lasers with UV or near-UV wavelengths as energy sources to print hydrogels, cells, proteins and ceramic materials $[36,37]$. The resolution varies from pico- to micro-scale features and is affected by many factors: the thickness of the biological materials on the film, their rheological properties, the energy of the laser pulse, the wettability of the substrate, and the printing speed and organization of the structure [38, 39].

Researchers have demonstrated the feasibility of using laser-based technology to print cells, for example, human dermal fibroblasts, mouse $\mathrm{C} 2 \mathrm{C} 12$ myoblasts, bovine pulmonary artery endothelial cells (BPAECs), breast cancer (MCF-7) cells and rat neural stem cells [39-41]. In 2013, Michael et al. [42] successfully created Graftskin skin substitutes by utilizing LAB technology, a landmark event in the field of laser-assisted bioprinting. Fibroblasts and keratinocytes were used as the cell sources to fabricate the skin constructs, which were subsequently transplanted into the skin folds of nude mice to perform an in vivo evaluation. Eleven days later, the graft adhered well to the tissue around the skin wound. The keratinocytes proliferated and differentiated well and grew to the skin stratum corneum and basal layer. Compared with other bioprinting technologies, LAB has unique advantages, including a nozzle-free, non-contact process, the printing of cells with high activity and high resolution, and the control of ink droplets and precise delivery characteristics. Ink bubble dynamics, shear stress and laser pulse energy all play important roles in the bioprinting process [43-45].

\section{Stereolithography}

Stereolithography (STL) technology is a solid freeform, nozzle-free technology that was developed in the late 1980s [46]. A liquid, photo-sensitive polymer formulation is solidified upon illumination. STL uses digital micromirror arrays to control the light intensity to polymerize light-sensitive polymer materials. This technique is mainly applied to fabricate structures from curable acrylics and epoxies. The number of photocrosslinkable polymers is increasing, and multiple resins can be used for one structure [32]. Digital light projection controls the printing process in this top-down system. Compared with other solid freeform techniques, STL has the highest fabrication accuracy, and an increasing number of materials can be used in this process. Furthermore, STL can print light-sensitive hydrogels layer-by-layer, and the total printing time depends only on the thickness of the structure [47].

However, in addition to these advantages, there are numerous restrictions, such as the lack of proper biocompatible and biodegradable polymers, harmful effects from residual toxic photocuring reagents, the inability to completely remove the supporting structure and the inability to form horizontal gradients in the constructs [46]. UV-sensitive photoinitiators were once used, although UV is harmful to cellular DNA and causes skin cancer. In 2015, Wang [47] investigated the use of customized visible light in a STL system, including a commercial beam projector and bioinks, a mixture of PEGDA, methacrylated gelatin (GelMA), and eosin Y-based photoinitiator. They first described the detailed protocol of the visible light-based STL system and revealed the necessity of an infrared ray (IR)-filtering water filter to the system. Their experimental results with NIH 3T3 cells demonstrated that this system with customized visible light could support the bioprinting of visible light-curable hydrogels with $50-\mu \mathrm{m}$ resolution and high cell viability $(\sim 85 \%)$ for at least 5 days.

\section{Key points of bioprinting}

The goal of tissue engineering is to fabricate 3D artificial tissues or organs composed of a scaffold, cells and a microenvironment that mimics the real environment of the human body. As a highly effective and accurate method to fabricate artificial tissue in vitro, printing achieves these three necessary components. This section will discuss the applications and limitations of the materials used in bioprinting, including biomaterials, cells and cell factors.

\section{Parameters of biomaterials}

In general, biomaterials can be categorized into a large variety of hydrogel, metallic, ceramic, polymeric and composite materials. The physical characteristics of biomaterials determines the optimal printing type. For example, low-viscosity materials are more attractive for bioprinting because cells can grow well in the low-pressure environment [48]. Other material properties, such 
as pore size and interconnectivity, also influence the encapsulated cells [49].

\section{Biocompatibility}

The biocompatibility of biomaterials is the first parameter to be considered when fabricating scaffolds and significantly limits the number of suitable materials. Scaffold materials must accommodate the encapsulated cells and the recipient's body. Thus, the implant must be cytocompatible and support cell growth, attachment, proliferation and migration but safe for the host and not cause severe inflammation or immunologic rejection.

Hydrogels are attractive materials for bioprinting because they are an enormous three-dimensional network of polymer chains holding a mass of water. For the processing of physical hydrogels, a polymer network is expected to form from the physical junctions between hydrogel macromolecules. The use of some photo-initiators and monomers during hydrogel crosslinking affects cell viability depending on radical concentration and the length of exposure [50]. However, more complex, functional and biocompatible hydrogels can be fabricated using bioprinting technology. Wüst et al. [51] reported the use of different amounts of HA to print a tunable alginate-gelatin hydrogel composite with a two-step crosslinking procedure. Human mesenchymal stem cells (hMSCs) were subsequently mixed with the hydrogel, and cell viability was detected. Approximately $85 \%$ of the cells were still viable after 3 days of in vitro culture. This experiment demonstrated that adding HA to the hydrogel in different concentrations enhances mechanical properties to match hard tissue reconstruction with no reduction in cell viability.

\section{Porosity and interconnectivity}

Pore shape, volume, size and geometry all directly affect the behavior of cells after adhesion to the scaffold. Different pore sizes in matrices can affect extracellular matrix development and are strictly correlated with cellular organization, collagen I assembly, and mineralization [52]. Porosity and interconnectivity play important roles in the ingrowth of surrounding tissues. Open and interconnected pores can allow oxygen and nutrients to be transported into the interior and eliminate the waste generated by cellular metabolism.
Domingos et al. [53] performed a systematic analysis of 3D-printed scaffolds to determine the effects of pore size and geometry on hMSC viability. Three different filament distances $(550,650$ and $750 \mu \mathrm{m})$ and filament patterns $\left(0^{\circ} / 90^{\circ}, 0^{\circ} / 60^{\circ} / 120^{\circ}\right.$ and $\left.0^{\circ} / 45^{\circ} / 90^{\circ} / 135^{\circ}\right)$ were designed to obtain complex internal geometries. Cells encapsulated in the structure with larger filament distances and fewer deposition angles behaved more actively. The results indicated the following: (1) cell adhesion, viability and proliferation were strongly influenced by the pore size and shape, whereby large quadrangular pores enhanced hMSC viability and proliferation; (2) cell morphology did not seem to be affected by pore topology, as demonstrated by the investigation of the shape factor.

\section{Mechanical properties}

Physical parameters are an indispensable part of tissue engineering scaffolds, particularly for the regeneration of hard tissues, such as bones and cartilages. Appropriate mechanical strength matching that of natural bones is very important. When artificial bones with high elastic moduli are implanted in situ, they may produce stress shielding and hinder new bone formation. The mechanical properties of human cortical and cancellous bone are generally described as in Table 2 .

Ceramics [54-57] such as TCP, CaP, $\mathrm{HA}$ and $\mathrm{SiO}_{2}$ are widely used in bone tissue engineering because of their excellent mechanical properties, osteoconductivity and comparability with bones. Some examples of bioprinted ceramic materials are listed in Table 3.

Most material components of bioink are derived from current materials used in tissue engineering and limit the application of printed scaffolds. In addition to good biocompatibility, high porosity and matching mechanical properties, the ideal material must have appropriate hydrophilicity, $\mathrm{pH}$ neutrality, and degradability without the formation of toxic macromolecules. Future development of manufacturing technology will enable printing of biofunctional scaffolds that perfectly mimic the extracellular matrix to provide cells with a microenvironment for adhesion, proliferation and directional differentiation.

\section{Classification and ink formulations}

A wide range of biomaterial inks which categorize polymers, ceramics, hydrogels and composites have been

Table 2 Characteristics of human cortical and cancellous bones

\begin{tabular}{llll}
\hline Bone type & Porosity $(\%)$ & Pore size $(\boldsymbol{\mu m})$ & Compressive strength $(\mathbf{M P a})$ \\
\hline Cortical bone & $3-12$ & $<500$ & $130-225$ \\
Cancellous bone & $50-90$ & $500-1000$ & $4-12$ \\
\hline
\end{tabular}


Table 3 3D-printed ceramic materials for tissue engineering

\begin{tabular}{|c|c|c|c|c|}
\hline Material & $\begin{array}{l}\text { Porosity and compressive } \\
\text { strength }\end{array}$ & Biological properties & Printing type & References \\
\hline $\mathrm{SiO}_{2} / \mathrm{ZnO}$ & $32-52 \%$ and $2-10 \mathrm{MPa}$ & $\begin{array}{l}\text { Increased mechanical strength } \\
\text { and cellular proliferation }\end{array}$ & Inkjet-based bioprinting & {$[105]$} \\
\hline $\begin{array}{l}\text { B-TCP/POC (poly-1,8- } \\
\text { octanediol-co-citrate) }\end{array}$ & $45 \%$ & $\begin{array}{l}\text { High compressive modulus and } \\
\text { good drug delivery } \\
\text { performance }\end{array}$ & Micro-droplet jetting & [106] \\
\hline $\mathrm{CaSiO}_{3}$ & $70 \%$ and $7 \mathrm{MPa}$ & $\begin{array}{l}\text { Enhanced cell attachment and } \\
\text { osteogenic activity }\end{array}$ & $3 \mathrm{D}$ printing & {$[100]$} \\
\hline $\mathrm{CaCO}_{3} / \mathrm{SiO}_{2}$ & $34 \%$ and $47 \mathrm{MPa}$ & $\begin{array}{l}\text { resulting in improved } \\
\text { mechanical properties and } \\
\text { good cell affinity }\end{array}$ & Laser-aided gelling (LAG) & {$[107]$} \\
\hline Sr-Mg doped TCP & 4-12 MPa & $\begin{array}{l}\text { Increased osteons and, } \\
\text { consequently, an enhanced } \\
\text { network of blood vessel } \\
\text { formation and osteocalcin } \\
\text { expression }\end{array}$ & 3D printing & [108] \\
\hline HA/PVOH (poly(vinyl)alcohol) & $55 \%$ and $0.88 \mathrm{MPa}$ & $\begin{array}{l}\text { Osteoconduction and } \\
\text { osteointegration in vivo }\end{array}$ & $3 \mathrm{D}$ printing & [109] \\
\hline $\begin{array}{l}\text { HSP bioceramic (hollow- } \\
\text { struts-packed) }\end{array}$ & $65-85 \%$ and $\sim 5 \mathrm{MPa}$ & $\begin{array}{l}\text { Significantly improved cell } \\
\text { attachment and proliferation; } \\
\text { promotion of formation of new } \\
\text { bone tissue in the center of the } \\
\text { scaffolds }\end{array}$ & $\begin{array}{l}\text { A modified coaxial } \\
3 \text { D printing }\end{array}$ & {$[110]$} \\
\hline
\end{tabular}

developed in the printing technology [58]. Compared to polymer and ceramic, hydrogel inks have received much more attention, and significant progress have already been made to design novel ink formulations. A new 3D bioprinting technique called freeform reversible embedding of suspended hydrogels (FRESH) has been introduced by Feinberg AW [59]. The innovation of this technology is what deposits and crosslinks one kind of hydrogel inks into another that can be considered as a support carrier. It has been successfully applied in the printing of human femurs, branched coronary arteries, trabeculated embryonic hearts and human brains [60].

The lack of diversity in "biomaterial inks" became barriers to the widespread applications of 3D printing. UV light, chemical cross-linking, and high temperatures in the materials machining negatively impact most biologically activities. However, utilizing cellularized matrix gels lacked initial mechanical strength. The balance between structural strength and biocompatible processing is hard to satisfy scientists [61]. In the future, more bioactive and more mechanically stable must be developed to ultimately serve as the "bioink" for bioprinting tissue constructs.

\section{Bioprinting cells}

Cell printing is the key element for the printing of tissue and organs. However, the choice of bioink materials is limited by the stringent printing conditions. The stiffness, functional groups, and surface morphology of biomaterials have a significant impact on cellular behavior. Cells are usually encapsulated in biodegradable hydrogels that mimic a tissue-like environment for building bioprinted ink [62]. The characteristics of hydrogels can protect the inner cells from the shear force generated in the printing process and maintain their bio-functions, such as the self-renewal ability and multi-lineage differentiation potency of stem cells. The cytocompatibility of laserassisted cell printing technology with cells post-deposition was recently demonstrated, and this technique has been widely used for its high resolution and accuracy in single-cell deposition.

\section{Viability of post-printed cells}

$\mathrm{CHO}$ and embryonic motoneuron cells [29] were first successfully deposited into pre-defined patterns in 2005 . That study emphasized the need to study the biocompatibility of the inkjet printing process and the ability to encapsulate cells into bioink. The results were satisfactory, and less than $8 \%$ cell death was observed. Researchers [62] have successfully constructed HepG2-loaded GelMA hydrogels exhibiting high cell viability of greater than $95 \%$ for at least 8 days. These achievements demonstrated the possibility of bioprinting complex, cellladen hydrogel tissue constructs. Cells embedded in the hydrogels may remain in a non-proliferating state [63]. Neufurth et al. used the calcium salt of polyphosphate 
(polyp-Ca2 $2^{+}$-complex) as a second layer on top of an inner sodium alginate hydrogel surface, which strongly promoted cell proliferation and enhanced the hydrogel mechanical strength.

Bioprinted cells maintain their proliferation and differentiation abilities in vitro, an important step in the development of tissue constructs. Lorber et al. [64] reported that adult rat RGCs (retinal ganglion cells) and glia could be successfully printed by a piezoelectric inkjet printing method. No significant differences in cell survival and outgrowth were observed between the non-printed control group and the printed group. Additionally, coating a glial substrate first and then printing RGCs on top enhanced the functional activity of the cells. Future goals include printing other cells of the retina, particularly the light-sensitive photoreceptors, with exciting implications for the printing of a functional retina.

\section{Bioprinting stem cells}

Stem cells, including embryonic stem cells (ESCs), BMSCs and ASCs, can be printed and patterned by precise deposition of picoliter ( $\mathrm{pl}$ ) volumes of fluid or laser-aided accurate localization. An important concern in stem cell printing is that the activity of stem cells, including proliferation and pluripotency, may change during the printing process. Levato et al. [65] encapsulated MSCs in gelatin methacrylamide-gellan gum bioinks that combined bioprinting with microcarrier technology. This bioprinting approach allowed cells to be deposited internally with $90 \%$ viability after 3 days, and the cells were induced to osteogenic differentiation, with increased expression of bone markers such as ALP and OCN. MSCs were submerged in perfluorotributylamine $(\mathrm{C} 12 \mathrm{~F} 27 \mathrm{~N})$ as a hydrophobic high-density fluid to be printed in the desired shape [66]. A printed vascular bifurcation maintained its shape and dimensions for more than 6 months.

In the laser-assisted field, MSCs [67] were printed based on laser-induced forward transfer (LIFT) for the construction of scaffold-free autologous grafts. The seed cells survived the complete printing procedure and maintained their ability to proliferate and continue differentiating into the osteogenic lineage. Laser-induced jet formation and jet dynamics were explored using timeresolved imaging [45]. Slow jets were unperturbed, with increased stability and retention of stem cells with very high viability and high resolution. Ultraviolet (UV) light used in traditional laser-assisted printing technology might be damaging to the cellular DNA. Lin et al. [68] reported a visible light-based projection STL system that successfully incorporated hASCs in hydrogel scaffolds.

\section{Single-cell patterning}

As bioprinting technology has developed, single-cell deposition onto two-dimensional (2D) and into 3D environments has been used to explore cell behavior and monitor responses to growth, physical stimulation, cytokines and metabolite factors at the cellular level. A single-cell throughput system was also utilized to explore stem cell characteristics [69]. Based on the microdroplet throughput, the authors isolated and patterned single cells from heterogeneous cell suspensions. The printed cells maintained high viability of greater than $95 \%$, and 11 stem cell markers (including Kit and Notch1) were collected and analyzed from the genomic information. In Ma et al's work [70], researchers utilized a laser-patterned method to control MSC alignment to create a parallel-aligned morphology and studied cardiogenic differentiation and contractile function. Single-cell arrays have been widely utilized in neural networks. Dinh et al. [71] constructed compartmentalized brain models with single-cell precision based on microfluidic methods.

Significant progress has been made in controlling printing conditions to ensure minimal damage to cells and adequately mimic the extracellular environment. However, to print tissue structures, different cell types must be placed in specific locations, and stem cell differentiation must be controlled to produce the desired cell types [14]. Organ printing remains a long-term goal, and micro-organ printing has more potential in clinical applications. For example, islet cells with secretory capacity account for only $2 \%$ of pancreas cells. Printing these functional cells and reintroducing them into patients may allow patients without a complete pancreas to continue producing insulin.

\section{Extracellular microenvironment}

The extracellular microenvironment or niche provides various stimuli, such as physical, chemical and biological factors, to direct cell adhesion, proliferation and differentiation. Obvious effects on cell behavior have been confirmed by directly designing the surface morphology of scaffolds [72].

Biological molecules, including proteins and nucleic acids, have been successfully deposited with bioprinting technologies such as inkjet printing [14]. An advantage of inkjet printing is the ability to control the concentration gradient of internal ingredients using different bioink densities [73].

Growth factors such as BMP2, epidermal growth factor (EGF) and fibroblast growth factor 2 (FGF-2) have also been measured by molecular patterning. To print 3D artificial tissues, studies of 2D molecular arrays may provide clues about the function of growth factors in their niche. 


\section{Advanced applications of bioprinted tissues and organs}

Artificial tissues and organs are printed by depositing cells, biomaterials and molecules layer by layer. Bioprinting has the advantage of good resolution of the input cells. Using this technology, great efforts have been made in developing bioprinting technologies to attempt to print blood vessels [74], hearts [75], bone [76], cartilage [77], kidneys [78], skin [79], nerves and other tissues (Table 4). Figure 3 shows that the bioprinting technology has a wide range of applications from the molecular level such as DNA and protein to organ level.

\section{Blood vessel and heart printing}

As the mode of transport for nutrition and metabolic waste, functional blood vessels play important roles in cardiovascular diseases [80] and the construction of artificial organs, particularly these with a rich blood supply. Advances in developmental biology and iconography have enabled significant progress in printing vasculature in vitro. However, due to the unique functions and specific structures of the vasculature in different tissues, creating a vascular system remains a critical, unmet challenge.

Bioprinting enables the fabrication of network structures using hydrogels or other materials as bioink. Bertassoni et al. [81] successfully bioprinted a vascular network with GelMA, which improved metabolic transportation, cellular viability and the formation of endothelial monolayers. Kolesky et al. [82] successfully co-printed multiple materials with cells and vasculature using thermally reversible gelation to fabricate complex tissues.

In the printing of cardiac valves, tissue-engineered valve scaffolds are generally focused on the rebuilding of the aortic valve [24]. Researchers have performed extensive studies of printing aortic valve structures with hydrogels [30, 31, 83]. Cell-laden, valve-shaped structures were printed with a high cell survival rate (greater than $90 \%$ ). However, bioink materials are deficient in flexibility and elasticity, and their mechanical characteristics still do not meet clinical needs.

\section{Bone and cartilage tissue printing}

Bone and cartilage regeneration is the most mature field utilizing printing technology because the composition of hard tissues is uncomplicated and is mainly composed of inorganic elements. A variety of biomaterials have been produced to construct bone and cartilage scaffolds by many manufacturing approaches, including gas foaming $[84,85]$, salt leaching $[86,87]$ and freeze drying [88, 89]. However, the structural and mechanical properties of artificial scaffolds can be more accurately controlled by $3 \mathrm{D}$ bioprinting than by other technologies.
A cement powder system was recently fabricated containing HA and TCP as the ideal composition for human bone replacement to repair large defects [90]. The dimensional accuracy of the bioprinted scaffolds was greater than $96.5 \%$. In Gao's work [91], hMSCs and nanoparticles of bioactive glass (BG) and HA were co-printed to control the spatial placement of cells. hMSCs encapsulated in this compound exhibited high cell viability $(86.62 \pm 6.02 \%)$ and compressive modulus (358.91 $\pm 48.05 \mathrm{kPa})$ after 21 days in culture. In Park et al. work [92], HA and Col-1 hydrogels printed as tissue-mimetic structures were investigated independently to elucidate their effects on the behavior of chondrocytes and osteoblasts. Chondrocytes on HA hydrogels and osteoblasts on Col-1 hydrogels maintained better proliferative capacity and cell function than chondrocytes on Col-1 hydrogels and osteoblasts on HA hydrogels.

Bioprinting has been a popular technology for the creation of cartilage tissue engineering scaffolds from a variety of materials, ranging from ceramics to nanomaterials. Markstedt et al. [77] developed a printable bioink using a combination of nanofibrillated cellulose and alginate with human chondrocytes as living soft tissue. The mixture exhibited excellent shear-thinning behavior and cell viability of $86 \%$ after 7 days of 3D culture. The high plasticity of the ink allowed shapes resembling cartilage tissues, such as an ear and a meniscus, to be printed successfully.

Although printable scaffolds have been extensively applied in bone and cartilage tissue engineering, bioinks with suitable physical properties are still needed.

\section{Skin}

Skin protects the body from attack by foreign substances and maintains the integrity of the body. Many chronic diseases and burn wounds cause irreversible damage to skin, and thus bioprinting technology is particularly critical in the preparation of skin substitutes for transplantation to repair damaged skin.

The LAB technique has been applied to the printing of bio-skin. Michael et al. [42] successfully created skin substitutes using LAB technology and transplanted them to skin wounds of nude mice. Eleven days later, the graft was able to adhere well to the tissue around the skin wound, and the cells in the graft were able to proliferate and differentiate. In 2014, Lee et al. used keratinocytes and fibroblasts as materials to bioprint skin tissue. The resulting skin tissue had representative morphology and biology. The skin bioprinted by 3D technology was able to maintain its shape and had high flexibility, reproducibility and culture throughput. In addition, cells that cause skin diseases can be added to the biomaterials, and skin tissue printed with pathogenic cells can be used to study the pathophysiology of skin diseases [93]. 


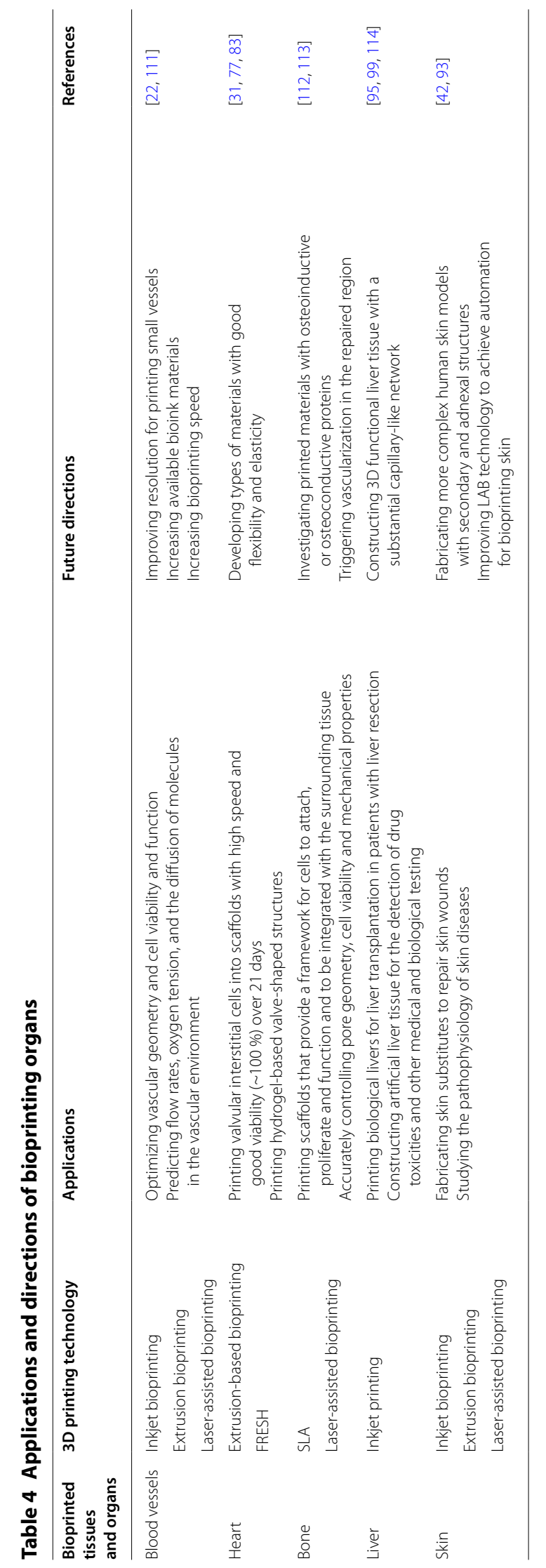




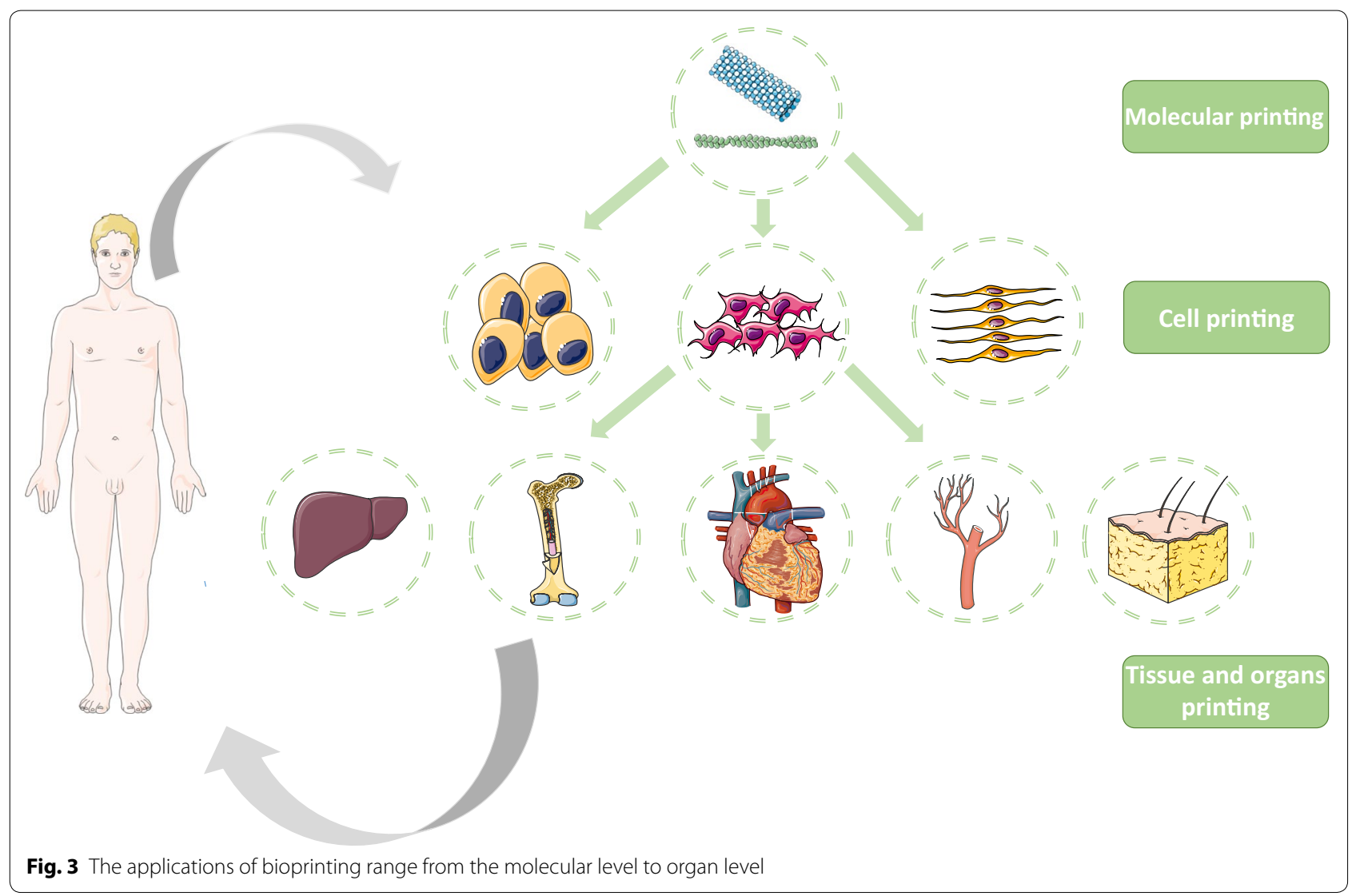

\section{Liver tissue printing}

Compared to other organs, the liver has strong regeneration ability. Patients who require liver transplantation can receive lobes of liver from a healthy donor [94] or can also wait for their own liver tissue to regenerate. However, healthy donors are in short supply, and the regeneration period for self-liver tissue is long. Therefore, bioprinting of liver tissue by tissue engineering is particularly important.

Many researchers have studied liver bioprinting. Primary hepatocytes and stem cell-derived hepatocytes have been used as the bioink to bioprint liver tissue [95]. Although the cells lose a certain amount of activity and functionality in the printing process, liver tissue containing both cell types can be sustained for a period of time. In contrast to traditional printing technologies, $3 \mathrm{D}$ printing technology can provide the exact size and shape of the liver suitable for the needs of patients with liver resection [96]. Recently, a new technique has been used to maintain cell activity and functionality for longer times [97]. The technique utilizes bioprinting technology to form structures called "canaliculi" that are similar to the liver hepatic cord. The primary hepatocytes and the "canaliculus" structures are cultured together in the collagen matrix. Then, a biomimetic ECM system evaluates the activity and functionality of the primary hepatocytes on different ECM-based hydrogels [98]. After the activity and functionality of the primary hepatocytes have been confirmed, the cells can be maintained for 4 weeks. Further increases in cellular activity would facilitate expanded applications of bioprinted liver tissue. Chang et al. [99] also demonstrated that multilayered tissues can be used as in vitro 3D liver models. This multilayered tissue contained rat and human hepatocytes, and the multilayered cellular architecture could be used as a liver analog to help detect drug toxicities and for other medical and biological testing. Thus, 3D bioprinted livers can be used not only for liver resection in patients and other liver surgeries but also for simulated liver experiments in vitro.

The use of biological printing for the liver would have profound impact. Although some achievements have been made, hurdles must still be overcome, including cost and time, and the mechanical properties of printed liver tissue must be highly consistent with that of the native liver. 


\section{Limitations of and future directions for bioprinting}

Different types of 3D printing are utilized for applications that range from studies of cellular behavior to investigations of tissue pharmacodynamics or toxicological mechanisms. Although 3D printers have high precision and reproducibility, printing organs and functional tissues with entire structures still requires assembly layer-bylayer with "bio-glue." The main technological barriers are suitable bioinks with good biocompatibility and mechanical strength that can be used to achieve biological function. Hydrogels and ceramics have been used for soft and hard tissue engineering, respectively $[50,55,100]$. Meanwhile, personalized 3D printing technology will lead to a series of regulatory hurdles referring to the specified printed product supervision. However, it is urgent for the management establishing and perfecting relevant laws and regulations to guarantee sustainable development of 3D printing technology. Studies in the near future will likely bring great progress in printing micro-organs, such as pancreas islet tissues that function in the absence of the complete pancreas structure, which will benefit hundreds of millions of diabetic patients around the globe. Chang [101] successfully fabricated micro-livers that were utilized for testing drug metabolism.

As printing technology develops, additional biomimetic, tissue engineered organs will be created. Decreases in reestablishment time and cost should also be addressed before bioprinting of organs can be applied in the clinic.

\section{Conclusions}

Bioprinting technology has drawn more and more attention as a fabrication methodology for producing scaffolds, cells, tissues and organs. It has advantages in precise control, repeatability and individual design, yet many challenges remains for building complex tissues including multiple cell types in a spatial structure. More importantly, bioink materials development, resolution enhancement and vascularization are necessary to apply bioprinting technology clinically.

\begin{abstract}
Abbreviations
ECM: extracellular matrix; 3D: three-dimensional; AM: additive manufacturing; CAD/CAM: computer-aided design/computer-aided manufacturing; CHO: Chinese hamster ovary; PAB: pressure-assisted bioprinting; MPSCs: multipotent stromal cells; LAB: laser-assisted bioprinting; SLS: selective laser sintering; PCL: polycaprolactone; HA: ydroxyapatite; TCP: tricalcium phosphate; CHAp/PLLA: hydroxyapatite/poly (I-lactic acid); PVA: polyvinyl alcohol; STL: stereolithography; hMSCs: human mesenchymal stem cells; ESCs: embryonic stem cells; LIFT: laser-induced forward transfer; EGF: epidermal growth factor; FGF-2: fibroblast growth factor 2; FRESH: freeform reversible embedding of suspended hydrogels.
\end{abstract}

\section{Authors' contributions}

$J \mathrm{~L}$ and $\mathrm{MC}$ contributed to gathering the data relevant for this review. XF and $\mathrm{HZ}$ drafted and revised the manuscript. JL prepared the figures. MC participated in the design of tables. All authors read and approved the final manuscript.
Acknowledgements

The authors thank all those who participated in the revision of this review.

Competing interests

The authors declare that they have no competing interests.

Availability of data and materials

Data sharing not applicable to this article as no datasets were generated or analysed during the current study.

\section{Funding}

This work was sponsored by National High Technology Research and Development Program (863 Program) (2015AA020311); SJTU Medical \& Engineering Cross Fund (YG2014MS03); Shanghai Science Committee Basic Research Leading Project (No. 13JC1403800).

Received: 2 June 2016 Accepted: 5 September 2016

Published online: 20 September 2016

\section{References}

1. Huang JMY, Millis JM. Government policy and organ transplantation in China. Lancet. 2008;372:1937-8.

2. Zhang Q, Johnson JA, Dunne LW, Chen Y, lyyanki T, Wu Y, Chang El, Branch-Brooks CD, Robb GL, Butler CE. Decellularized skin/adipose tissue flap matrix for engineering vascularized composite soft tissue flaps. Acta Biomater. 2016;35:166-84.

3. Futrega K, Palmer JS, Kinney M, Lott WB, Ungrin MD, Zandstra PW, Doran MR. The microwell-mesh: a novel device and protocol for the high throughput manufacturing of cartilage microtissues. Biomaterials. 2015;62:1-12.

4. Shamaz BH, Anitha A, Vijayamohan M, Kuttappan S, Nair S, Nair MB. Relevance of fiber integrated gelatin-nanohydroxyapatite composite scaffold for bone tissue regeneration. Nanotechnology. 2015;26:405101.

5. Lee $\mathrm{CH}$, Lee FY, Tarafder S, Kao K, Jun Y, Yang G, Mao JJ. Harnessing endogenous stem/progenitor cells for tendon regeneration. J Clin Invest. 2015;125:2690-701.

6. Thankam FG, Muthu J. Alginate-polyester comacromer based hydrogels as physiochemically and biologically favorable entities for cardiac tissue engineering. J Colloid Interface Sci. 2015;457:52-61.

7. Rouwkema J, Rivron NC, van Blitterswijk CA. Vascularization in tissue engineering. Trends Biotechnol. 2008;26:434-41.

8. Jones AC, Arns CH, Hutmacher DW, Milthorpe BK, Sheppard AP, Knackstedt MA. The correlation of pore morphology, interconnectivity and physical properties of 3D ceramic scaffolds with bone ingrowth. Biomaterials. 2009;30:1440-51.

9. Hollister SJ, Maddox RD, Taboas JM. Optimal design and fabrication of scaffolds to mimic tissue properties and satisfy biological constraints. Biomaterials. 2002;23:4095-103.

10. Lee J, Cuddihy MJ, Kotov NA. Three-dimensional cell culture matrices: state of the art. Tissue Eng Part B Rev. 2008;14:61-86.

11. Leong KF, Chua CK, Sudarmadji N, Yeong WY. Engineering functionally graded tissue engineering scaffolds. J Mech Behav Biomed Mater. 2008;1:140-52.

12. Zong $X$, Bien H, Chung CY, Yin L, Fang D, Hsiao BS, Chu B, Entcheva E. Electrospun fine-textured scaffolds for heart tissue constructs. Biomaterials. 2005;26:5330-8.

13. Moroni L, de Wijn JR, van Blitterswijk CA. 3D fiber-deposited scaffolds for tissue engineering: influence of pores geometry and architecture on dynamic mechanical properties. Biomaterials. 2006;27:974-85.

14. Derby B. Printing and prototyping of tissues and scaffolds. Science. 2012:338:921-6.

15. Powers MK, Lee BR, Silberstein J. Three-dimensional printing of surgical anatomy. Curr Opin Urol. 2016;26:283-8.

16. Cui X, Breitenkamp K, Lotz M, D'Lima D. Synergistic action of fibroblast growth factor-2 and transforming growth factor-beta1 enhances bioprinted human neocartilage formation. Biotechnol Bioeng. 2012;109:2357-68. 
17. Poldervaart MT, Wang $\mathrm{H}$, van der Stok J, Weinans $\mathrm{H}$, Leeuwenburgh SC, Oner FC, Dhert WJ, Alblas J. Sustained release of BMP-2 in bioprinted alginate for osteogenicity in mice and rats. PLoS ONE. 2013;8:e72610.

18. Arslan-Yildiz A, Assal RE, Chen P, Guven S, Inci F, Demirci U. Towards artificial tissue models: past, present, and future of $3 \mathrm{D}$ bioprinting. Biofabrication. 2016;8:014103.

19. Lee SY, Kim HJ, Choi D. Cell sources, liver support systems and liver tissue engineering: alternatives to liver transplantation. Int J Stem Cells. 2015;8:36-47.

20. Boland T, Xu T, Damon B, Cui X. Application of inkjet printing to tissue engineering. Biotechnol J. 2006;1:910-7.

21. Cui X, Dean D, Ruggeri ZM, Boland T. Cell damage evaluation of thermal inkjet printed Chinese hamster ovary cells. Biotechnol Bioeng. 2010;106:963-9.

22. Murphy SV, Atala A. 3D bioprinting of tissues and organs. Nat Biotechnol. 2014;32:773-85.

23. Cui X, Boland T, D'Lima DD, Lotz MK. Thermal inkjet printing in tissue engineering and regenerative medicine. Recent Pat Drug Deliv Formul. 2012;6:149-55.

24. Jana S, Lerman A. Bioprinting a cardiac valve. Biotechnol Adv. 2015;33:1503-21.

25. Nakamura M, Kobayashi A, Takagi F, Watanabe A, Hiruma Y, Ohuchi K, Iwasaki Y, Horie M, Morita I, Takatani S. Biocompatible inkjet printing technique for designed seeding of individual living cells. Tissue Eng. 2005;11:1658-66

26. Saunders RE, Gough JE, Derby B. Delivery of human fibroblast cells by piezoelectric drop-on-demand inkjet printing. Biomaterials. 2008:29:193-203.

27. Seetharam R, Sharma SK. Purification and analysis of recombinant proteins. Biotechnology and Bioprocessing, vol 12. CRC Press; 1991.

28. Okamoto T, Suzuki T, Yamamoto N. Microarray fabrication with covalent attachment of DNA using bubble jet technology. Nat Biotechnol. 2000:18:438-41.

29. Xu T, Jin J, Gregory C, Hickman JJ, Boland T. Inkjet printing of viable mammalian cells. Biomaterials. 2005;26:93-9.

30. Duan B, Hockaday LA, Kang KH, Butcher JT. 3D bioprinting of heterogeneous aortic valve conduits with alginate/gelatin hydrogels. J Biomed Mater Res A. 2013;101:1255-64.

31. Hockaday LA, Kang KH, Colangelo NW, Cheung PY, Duan B, Malone E, Wu J, Girardi LN, Bonassar LJ, Lipson H, et al. Rapid 3D printing of anatomically accurate and mechanically heterogeneous aortic valve hydrogel scaffolds. Biofabrication. 2012;4:035005.

32. Chia HN, Wu BM. Recent advances in $3 D$ printing of biomaterials. J Biol Eng. 2015;9:4

33. Chien KB, Makridakis E, Shah RN. Three-dimensional printing of soy protein scaffolds for tissue regeneration. Tissue Eng Part C Methods. 2013;19:417-26.

34. Fedorovich $\mathrm{NE}$, Schuurman W, Wijnberg HM, Prins $\mathrm{HJ}$, van Weeren PR, Malda J, Alblas J, Dhert WJ. Biofabrication of osteochondral tissue equivalents by printing topologically defined, cell-laden hydrogel scaffolds. Tissue Eng Part C Methods. 2012;18:33-44.

35. Fedorovich NE, Wijnberg HM, Dhert WJ, Alblas J. Distinct tissue formation by heterogeneous printing of osteo- and endothelial progenitor cells. Tissue Eng Part A. 2011;17:2113-21.

36. Catros S, Fricain JC, Guillotin B, Pippenger B, Bareille R, Remy M, Lebraud E, Desbat B, Amedee J, Guillemot F. Laser-assisted bioprinting for creating on-demand patterns of human osteoprogenitor cells and nano-hydroxyapatite. Biofabrication. 2011;3:025001.

37. Trombetta R, Inzana J, Schwarz EM, Kates SL, Awad HA. 3D printing of calcium phosphate ceramics for bone tissue engineering and drug delivery. Ann Biomed Eng. 2016. doi:10.1007/s10439-016-1678-3.

38. Guillemot F, Souquet A, Catros S, Guillotin B. Laser-assisted cell printing: principle, physical parameters versus cell fate and perspectives in tissue engineering. Nanomedicine. 2010;5:507-15.

39. Guillemot F, Souquet A, Catros S, Guillotin B, Lopez J, Faucon M. Highthroughput laser printing of cells and biomaterials for tissue engineering. Acta Biomater. 2010;6:2494-500.

40. Barron JA, Wu P, Ladouceur HD, Ringeisen BR. Biological laser printing: a novel technique for creating heterogeneous 3-dimensional cell patterns. Biomed Microdevices. 2004;6:139-47.
41. Ringeisen BR, Kim H, Barron JA, Krizman DB, Chrisey DB, Jackman S, Auyeung RY, Spargo BJ. Laser printing of pluripotent embryonal carcinoma cells. Tissue Eng. 2004;10:483-91.

42. Michael S, Sorg H, Peck CT, Koch L, Deiwick A, Chichkov B, Vogt PM, Reimers K. Tissue engineered skin substitutes created by laser-assisted bioprinting form skin-like structures in the dorsal skin fold chamber in mice. PLoS ONE. 2013:8:e57741.

43. Serra P, Duocastella M, Fernández-Pradas JM, Morenza JL. Liquids microprinting through laser-induced forward transfer. Appl Surf Sci. 2009;255:5342-5.

44. Patrascioiu A, Fernández-Pradas JM, Palla-Papavlu A, Morenza JL, Serra P. Laser-generated liquid microjets: correlation between bubble dynamics and liquid ejection. Microfluidics Nanofluidics. 2014;16:55-63.

45. Ali M, Pages E, Ducom A, Fontaine A, Guillemot F. Controlling laserinduced jet formation for bioprinting mesenchymal stem cells with high viability and high resolution. Biofabrication. 2014;6:045001.

46. Melchels FP, Feijen J, Grijpma DW. A review on stereolithography and its applications in biomedical engineering. Biomaterials. 2010;31:6121-30.

47. Wang Z, Abdulla R, Parker B, Samanipour R, Ghosh S, Kim K. A simple and high-resolution stereolithography-based 3D bioprinting system using visible light crosslinkable bioinks. Biofabrication. 2015;7:045009.

48. Khatiwala C, Law R, Shepherd B, Dorfman S, Csete M. 3D cell bioprinting for regenerative medicine research and therapies. Gene Ther. 2012;7:1-19.

49. Tasoglu S, Demirci U. Bioprinting for stem cell research. Trends Biotechnol. 2013;31:10-9.

50. Nicodemus GD, Bryant SJ. Cell encapsulation in biodegradable hydrogels for tissue engineering applications. Tissue Eng Part B Rev. 2008;14:149-65.

51. Wust S, Godla ME, Muller R, Hofmann S. Tunable hydrogel composite with two-step processing in combination with innovative hardware upgrade for cell-based three-dimensional bioprinting. Acta Biomater. 2014;10:630-40.

52. Matsiko A, Gleeson JP, O'Brien FJ. Scaffold mean pore size influences mesenchymal stem cell chondrogenic differentiation and matrix deposition. Tissue Eng Part A. 2015;21:486-97.

53. Domingos M, Intranuovo F, Russo T, De Santis R, Gloria A, Ambrosio L, Ciurana J, Bartolo P. The first systematic analysis of 3D rapid prototyped poly(epsilon-caprolactone) scaffolds manufactured through BioCell printing: the effect of pore size and geometry on compressive mechanical behaviour and in vitro hMSC viability. Biofabrication. 2013;5:045004.

54. Lou T, Wang X, Song G, Gu Z, Yang Z. Structure and properties of PLLA/ beta-TCP nanocomposite scaffolds for bone tissue engineering. J Mater Sci Mater Med. 2015;26:5366.

55. Nadeem D, Smith CA, Dalby MJ, Meek RM, Lin S, Li G, Su B. Threedimensional $\mathrm{CaP} /$ gelatin lattice scaffolds with integrated osteoinductive surface topographies for bone tissue engineering. Biofabrication. 2015;7:015005

56. Yao Q, Wei B, Guo Y, Jin C, Du X, Yan C, Yan J, Hu W, Xu Y, Zhou Z, et al. Design, construction and mechanical testing of digital $3 \mathrm{D}$ anatomical data-based PCL-HA bone tissue engineering scaffold. J Mater Sci Mater Med. 2015:26:5360.

57. Leonardi E, Ciapetti G, Baldini N, Novajra G, Verne E, Baino F, Vitale-Brovarone $C$. Response of human bone marrow stromal cells to a resorbable $\mathrm{P}(2) \mathrm{O}(5)-\mathrm{SiO}(2)-\mathrm{CaO}-\mathrm{MgO}-\mathrm{Na}(2) \mathrm{O}-\mathrm{K}(2) \mathrm{O}$ phosphate glass ceramic for tissue engineering applications. Acta Biomater. 2010;6:598-606.

58. Jose RR, Rodriguez MJ, Dixon TA, Omenetto F, Kaplan DL. Evolution of Bioinks and Additive Manufacturing Technologies for 3D Bioprinting. ACS Biomater Sci Eng 2016. doi:10.1021/acsbiomaterials.6b00088.

59. Hinton TJ, Jallerat Q, Palchesko RN, Park JH, Grodzicki MS, Shue HJ, Ramadan MH, Hudson AR, Feinberg AW. Three-dimensional printing of complex biological structures by freeform reversible embedding of suspended hydrogels. Sci Adv. 2015;1:e1500758.

60. Duffy RMSY, Feinberg AW. Understanding the role of ECM protein composition and geometric micropatterning for engineering human skeletal muscle. Ann Biomed Eng. 2016;44:2076-89.

61. Guvendiren M, Molde J, Soares RMD, Kohn J. Designing biomaterials for 3D printing. ACS Biomater Sci Eng; 2016. doi:10.1021/ acsbiomaterials.6b00121.

62. Bertassoni LE, Cardoso JC, Manoharan V, Cristino AL, Bhise NS, Araujo WA, Zorlutuna P, Vrana NE, Ghaemmaghami AM, Dokmeci MR, 
Khademhosseini A. Direct-write bioprinting of cell-laden methacrylated gelatin hydrogels. Biofabrication. 2014;6:024105.

63. Neufurth M, Wang X, Schroder HC, Feng Q, Diehl-Seifert B, Ziebart T, Steffen R, Wang S, Muller WE. Engineering a morphogenetically active hydrogel for bioprinting of bioartificial tissue derived from human osteoblast-like SaOS-2 cells. Biomaterials. 2014;35:8810-9.

64. Lorber B, Hsiao WK, Hutchings IM, Martin KR. Adult rat retinal ganglion cells and glia can be printed by piezoelectric inkjet printing. Biofabrication. 2014;6:015001.

65. Levato R, Visser J, Planell JA, Engel E, Malda J, Mateos-Timoneda MA. Biofabrication of tissue constructs by 3D bioprinting of cell-laden microcarriers. Biofabrication. 2014;6:035020.

66. Duarte Campos DF, Blaeser A, Weber M, Jakel J, Neuss S, JahnenDechent W, Fischer H. Three-dimensional printing of stem cell-laden hydrogels submerged in a hydrophobic high-density fluid. Biofabrication. 2013;5:015003.

67. Gruene M, Deiwick A, Koch L, Schlie S, Unger C, Hofmann N, Bernemann I, Glasmacher B, Chichkov B. Laser printing of stem cells for biofabrication of scaffold-free autologous grafts. Tissue Eng Part $C$ Methods. 2011:17:79-87.

68. Lin H, Zhang D, Alexander PG, Yang G, Tan J, Cheng AW, Tuan RS. Application of visible light-based projection stereolithography for live cell-scaffold fabrication with designed architecture. Biomaterials. 2013:34:331-9.

69. Moon S, Kim Y-G, Dong L, Lombardi M, Haeggstrom E, Jensen RV, Hsiao L-L, Demirci U. Drop-on-demand single cell isolation and total RNA analysis. PLoS ONE. 2011;6:e17455.

70. Ma Z, Liu Q, Yang H, Runyan RB, Eisenberg CA, Xu M, Borg TK, Markwald R, Wang Y, Gao BZ. Laser patterning for the study of MSC cardiogenic differentiation at the single-cell level. Light Sci Appl. 2013;2:e68.

71. Dinh ND, Chiang YY, Hardelauf H, Baumann J, Jackson E, Waide S, Sisnaiske J, Frimat JP, van Thriel C, Janasek D, et al. Microfluidic construction of minimalistic neuronal co-cultures. Lab Chip. 2013;13:1402-12.

72. Roth EA, Xu T, Das M, Gregory C, Hickman JJ, Boland T. Inkjet printing for high-throughput cell patterning. Biomaterials. 2004;25:3707-15.

73. Campbell PG, Miller ED, Fisher GW, Walker LM, Weiss LE. Engineered spatial patterns of FGF-2 immobilized on fibrin direct cell organization. Biomaterials. 2005:26:6762-70.

74. Skardal A, Zhang J, Prestwich GD. Bioprinting vessel-like constructs using hyaluronan hydrogels crosslinked with tetrahedral polyethylene glycol tetracrylates. Biomaterials. 2010;31:6173-81.

75. Beyersdorf F. Three-dimensional bioprinting: new horizon for cardiac surgery. Eur J Cardiothorac Surg. 2014;46:339-41.

76. Sawkins MJ, Mistry P, Brown BN, Shakesheff KM, Bonassar LJ, Yang J. Cell and protein compatible 3D bioprinting of mechanically strong constructs for bone repair. Biofabrication. 2015;7:035004.

77. Markstedt K, Mantas A, Tournier I, Martinez Avila H, Hagg D, Gatenholm P. 3D bioprinting human chondrocytes with nanocellulose-alginate bioink for cartilage tissue engineering applications. Biomacromolecules. 2015;16:1489-96.

78. Bernhard JC, Isotani S, Matsugasumi T, Duddalwar V, Hung AJ, Suer E, Baco E, Satkunasivam R, Djaladat H, Metcalfe C, et al. Personalized 3D printed model of kidney and tumor anatomy: a useful tool for patient education. World J Urol. 2016;34:337-45.

79. Skardal A, Mack D, Kapetanovic E, Atala A, Jackson JD, Yoo J, Soker S. Bioprinted amniotic fluid-derived stem cells accelerate healing of large skin wounds. Stem Cells Transl Med. 2012;1:792-802.

80. Go AS, Mozaffarian D, Roger VL, Benjamin EJ, Berry JD, Borden WB, Bravata DM, Dai S, Ford ES, Fox CS, Franco S, Fullerton HJ, Gillespie C, Hailpern SM, Heit JA, Howard VJ, Huffman MD, Kissela BM, Kittner SJ, Lackland DT, Lichtman JH, Lisabeth LD, Magid D, Marcus GM, Marelli A, Matchar DB, McGuire DK, Mohler ER, Moy CS, Mussolino ME, Nichol G, Paynter NP, Schreiner PJ, Sorlie PD, Stein J, Turan TN, Virani SS, Wong ND, Woo D, Turner MB, American Heart Association Statistics Committee and Stroke Statistics Subcommittee. Heart disease and stroke statistics - 2013 update: a report from the American Heart Association. Circulation. 2012;127:e6-245. doi:10.1161/CIR.0b013e31828124ad.

81. Bertassoni LE, Cecconi M, Manoharan V, Nikkhah M, Hjortnaes J, Cristino AL, Barabaschi G, Demarchi D, Dokmeci MR, Yang Y, Khademhosseini A. Hydrogel bioprinted microchannel networks for vascularization of tissue engineering constructs. Lab Chip. 2014;14:2202-11.
82. Kolesky DB, Truby RL, Gladman AS, Busbee TA, Homan KA, Lewis JA. 3D bioprinting of vascularized, heterogeneous cell-laden tissue constructs. Adv Mater. 2014;26:3124-30.

83. Duan B, Kapetanovic E, Hockaday LA, Butcher JT. Three-dimensional printed trileaflet valve conduits using biological hydrogels and human valve interstitial cells. Acta Biomater. 2014;10:1836-46.

84. Chen W, Zhou H, Tang M, Weir MD, Bao C, Xu HH. Gas-foaming calcium phosphate cement scaffold encapsulating human umbilical cord stem cells. Tissue Eng Part A. 2012;18:816-27.

85. Thein-Han W, Xu HH. Prevascularization of a gas-foaming macroporous calcium phosphate cement scaffold via coculture of human umbilical vein endothelial cells and osteoblasts. Tissue Eng Part A. 2013;19:1675-85.

86. Kim TG, Chung HJ, Park TG. Macroporous and nanofibrous hyaluronic acid/collagen hybrid scaffold fabricated by concurrent electrospinning and deposition/leaching of salt particles. Acta Biomater. 2008:4:1611-9.

87. Mehrabanian M, Nasr-Esfahani M. HA/nylon 6,6 porous scaffolds fabricated by salt-leaching/solvent casting technique: effect of nano-sized filler content on scaffold properties. Int J Nanomedicine. 2011;6:1651-9.

88. Gercek I, Tigli RS, Gumusderelioglu M. A novel scaffold based on formation and agglomeration of PCL microbeads by freeze-drying. J Biomed Mater Res A. 2008;86:1012-22.

89. Alizadeh M, Abbasi F, Khoshfetrat AB, Ghaleh H. Microstructure and characteristic properties of gelatin/chitosan scaffold prepared by a combined freeze-drying/leaching method. Mater Sci Eng C Mater Biol Appl. 2013;33:3958-67.

90. Castilho M, Moseke C, Ewald A, Gbureck U, Groll J, Pires I, Tessmar J, Vorndran E. Direct 3D powder printing of biphasic calcium phosphate scaffolds for substitution of complex bone defects. Biofabrication. 2014;6:015006.

91. Gao G, Schilling AF, Yonezawa T, Wang J, Dai G, Cui X. Bioactive nanoparticles stimulate bone tissue formation in bioprinted threedimensional scaffold and human mesenchymal stem cells. Biotechnol J. 2014;9:1304-11.

92. Park JY, Choi JC, Shim JH, Lee JS, Park H, Kim SW, Doh J, Cho DW. A comparative study on collagen type I and hyaluronic acid dependent cell behavior for osteochondral tissue bioprinting. Biofabrication. 2014;6:035004

93. Lee V, Singh G, Trasatti JP, Bjornsson C, Xu X, Tran TN, Yoo SS, Dai G, Karande P. Design and fabrication of human skin by three-dimensional bioprinting. Tissue Eng Part C Methods. 2014;20:473-84.

94. Zein NN, Hanouneh IA, Bishop PD, Samaan M, Eghtesad B, Quintini C, Miller C, Yerian L, Klatte R. Three-dimensional print of a liver for preoperative planning in living donor liver transplantation. Liver Transpl. 2013;19:1304-10.

95. Bale SS, Vernetti L, Senutovitch N, Jindal R, Hegde M, Gough A, McCarty WJ, Bakan A, Bhushan A, Shun TY, et al. In vitro platforms for evaluating liver toxicity. Exp Biol Med. 2014;239:1180-91.

96. Ikegami T, Maehara Y. Transplantation: 3D printing of the liver in living donor liver transplantation. Nat Rev Gastroenterol Hepatol. 2013;10:697-8.

97. Nakao Y, Kimura H, Sakai Y, Fujii T. Bile canaliculi formation by aligning rat primary hepatocytes in a microfluidic device. Biomicrofluidics. 2011;5:22212.

98. Skardal A, Smith L, Bharadwaj S, Atala A, Soker S, Zhang Y. Tissue specific synthetic ECM hydrogels for $3 D$ in vitro maintenance of hepatocyte function. Biomaterials. 2012;33:4565-75.

99. Chang R, Emami K, Wu H, Sun W. Biofabrication of a three-dimensional liver micro-organ as an in vitro drug metabolism model. Biofabrication. 2010:2:045004.

100. Zhu MZJ. Three-dimensional printing of cerium-incorporated mesoporous calcium-silicate scaffolds for bone repair. J Mater Sci. 2016;51:836-44.

101. Chang RC, Emami K, Jeevarajan A, Wu H, Sun W. Microprinting of liver micro-organ for drug metabolism study. Methods Mol Biol. 2011:671:219-38

102. Chien KB, Aguado BA, Bryce PJ, Shah RN. In vivo acute and humoral response to three-dimensional porous soy protein scaffolds. Acta Biomater. 2013;9:8983-90.

103. Haberstroh K, Ritter K, Kuschnierz J, Bormann KH, Kaps C, Carvalho C, Mulhaupt R, Sittinger M, Gellrich NC. Bone repair by cell-seeded 
3D-bioplotted composite scaffolds made of collagen treated tricalciumphosphate or tricalciumphosphate-chitosan-collagen hydrogel or PLGA in ovine critical-sized calvarial defects. J Biomed Mater Res B Appl Biomater. 2010;93:520-30.

104. Lim TC, Chian KS, Leong KF. Cryogenic prototyping of chitosan scaffolds with controlled micro and macro architecture and their effect on in vivo neo-vascularization and cellular infiltration. J Biomed Mater Res A. 2010;94:1303-11.

105. Fielding GA, Bandyopadhyay A, Bose $\mathrm{S}$. Effects of silica and zinc oxide doping on mechanical and biological properties of 3D printed tricalcium phosphate tissue engineering scaffolds. Dent Mater. 2012;28:113-22.

106. Gao L, Li C, Chen F, Liu C. Fabrication and characterization of toughness-enhanced scaffolds comprising beta-TCP/POC using the freeform fabrication system with micro-droplet jetting. Biomed Mater. 2015;10:035009.

107. Chang CH, Lin CY, Liu FH, Chen MH, Lin CP, Ho HN, Liao YS. 3D printing bioceramic porous scaffolds with good mechanical property and cell affinity. PLoS ONE. 2015;10:e0143713.

108. Tarafder S, Dernell WS, Bandyopadhyay A, Bose S. SrO- and MgOdoped microwave sintered 3D printed tricalcium phosphate scaffolds: mechanical properties and in vivo osteogenesis in a rabbit model. J Biomed Mater Res B Appl Biomater. 2015;103:679-90.
109. Cox SC, Thornby JA, Gibbons GJ, Williams MA, Mallick KK. 3D printing of porous hydroxyapatite scaffolds intended for use in bone tissue engineering applications. Mater Sci Eng C Mater Biol Appl. 2015;47:237-47.

110. Luo Y, Zhai D, Huan Z, Zhu H, Xia L, Chang J, Wu C. Three-dimensional printing of hollow-struts-packed bioceramic scaffolds for bone regeneration. ACS Appl Mater Interfaces. 2015;7:24377-83.

111. Paulsen SJ, Miller JS. Tissue vascularization through 3D printing: will technology bring us flow? Dev Dyn. 2015;244:629-40.

112. Bose SVS, Bandyopadhyay A. Bone tissue engineering using 3D printing. Mater Today. 2013;16:496-504

113. Xia Y, Zhou P, Cheng X, Xie Y, Liang C, Li C, Xu S. Selective laser sintering fabrication of nano-hydroxyapatite/poly-epsilon-caprolactone scaffolds for bone tissue engineering applications. Int J Nanomedicine. 2013;8:4197-213.

114. Lee JW, Choi YJ, Yong WJ, Pati F, Shim JH, Kang KS, Kang IH, Park J, Cho DW. Development of a 3D cell printed construct considering angiogenesis for liver tissue engineering. Biofabrication. 2016;8:015007.

\section{Submit your next manuscript to BioMed Central and we will help you at every step:}

- We accept pre-submission inquiries

- Our selector tool helps you to find the most relevant journal

- We provide round the clock customer support

- Convenient online submission

- Thorough peer review

- Inclusion in PubMed and all major indexing services

- Maximum visibility for your research

Submit your manuscript at www.biomedcentral.com/submit 